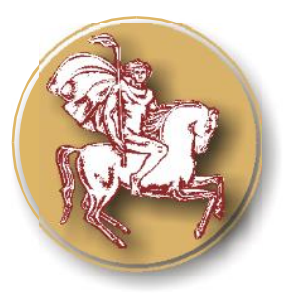

Review

\title{
HISTOLOGICAL, PHYSICOCHEMICAL AND MICROBIOLOGICAL CHANGES IN FRESH AND FROZEN/THAWED FISH
}

\author{
M. Strateva*, G. Penchev \\ Department of Veterinary Anatomy, Histology and Embryology, Faculty of Veterinary Medicine, \\ Trakia University, Stara Zagora, Bulgaria
}

\begin{abstract}
The production and supply of fish as food is constantly growing worldwide. Various methods are applied to extend its shelf life, one of them being freezing. According to European Union legislation, the state of the food and its treatment must be indicated on the label. If the food had been frozen prior to marketing and then sold thawed, this information must be provided to the consumer by labelling it. Otherwise, this is considered a fraud to the consumer since freezing significantly degrades the quality of fish. Histological, physicochemical and microbiological changes in the muscle tissue of frozen fish occur. Different methods may be applied to distinguish between fresh and frozen and them thawed fish, of which histological examination is a reliable method.
\end{abstract}

Key words: fish, freezing, histological changes

\section{INTRODUCTION}

Worldwide, fish production is constantly growing, with producers facing the challenge of meeting market dynamics and consumer expectations for safe and high quality products. The supply of fish as food is increasing at an average annual rate of $3.2 \%$. According to FAO, worldwide fish consumption per capita has increased from $9 \mathrm{~kg}$ in 1961 to $20.5 \mathrm{~kg}$ in 2017. Total fish production reached the record 171 million tonnes in 2016, of which $88 \%$ are used for human consumption. This impressive development is due to population growth, rising incomes and urbanization, as well as the solid expansion of fish farming and more efficient ways of distribution (1).

The way fish is stored has an important role to play in consumer safety. According to Regulations 1169/2011 (2) and 1379/2013 (3), information on the state of the food or its specific treatment must be indicated on the label. If the food had been frozen before marketing and then sold thawed, this should be

\footnotetext{
*Correspondence to: Mariyana Strateva, Department of Veterinary Anatomy, Histology and Embryology, Faculty of Veterinary Medicine, Trakia University, 6000 Stara Zagora, Bulgaria, mariyana.pepova@gmail.com
}

indicated on the label. Regardless of providing such information, it is very difficult for the consumer to distinguish between fresh and frozen and subsequently thawed fish only by organoleptic characteristics (4). In addition, the replacement of fresh fish with frozen and thawed fish should be considered a fraud (5). Freezing causes changes in the muscle tissue of fish. The objective of this review is to compare the histological, physicochemical and microbiological changes in muscle tissue of fresh and frozen/thawed fish.

\section{Anatomical characteristics of fish muscles}

The main structural and functional unit of striated muscle tissue is the muscle fiber or the so-called rhabdomyocyte. Each muscle fiber contains subunits called myofibrils located longitudinally and in parallel to each other. Myofibrils extend along the length of rhabdomyocyte, as they are its structural and functional units and occupy most of its volume. The remaining smaller part is occupied by nuclei (visualized in the peripheral area of the fibers), sarcolemma and sarcoplasm $(6,7)$. According to Delos et al. (2013) (8) The plasmolemma (sarcolemma) encompasses every muscle fiber. On the outside, the skeletal muscles are covered by a thicker layer of 
connective tissue, referred to as epimysium. Each muscle fiber is surrounded by a thinner layer of connective tissue, referred to as endomysium. Bach at al. (2004) (9) give an idea of how a muscle bundle is structured. According to the authors, it includes muscle fibers originating from myoblasts. Jasra et al. (2001) (10) claim that white and red (dark) muscle fibers are the two most common types in bony fish and are not evenly distributed and in the same proportion. In fish white muscle fibers, also referred to as fast fibers, are predominant, while slow red fibers are positioned superficially along the lateral line, under the skin and at the base of the fins. There are data on the content of lipids in muscle fibers, and they indicate that in greater quantity they are more like red fibers. The red colour of the fibers comes from the large amount of myoglobin they contain. Literature describes the so-called Sonic fibers, which are different from red and white muscle fibers. An indicator by which they can be determined is their structure and the unconventional arrangement of their myofibrils. The so-called mosaic fibers, which do not have a specific place, are described. According to scientific studies in carp and trout, these fibers can be found placed among others $(7,11-13)$. The structure of fish muscles is influenced by the species, age and size of the fish and its nutritional status (14). The amount of myoglobin in the dark fish muscles, which is a specific tissue of the fish, equals $81-99 \%$. The remaining muscles with a small amount of pigment proteins are referred to as white (ordinary) muscles, which is actually the main edible part of freshwater fishes (15). White muscle fibers are the main muscle mass, while red muscle fibers are found under the skin as a thin lateral sublayer (16). The dark muscles occupy $10-13 \%$ of the muscles in carp and are located on the surface of the lateral line and between the back and abdomen. In addition, dark muscles have a higher lipid content and less crude protein and moisture (15). According to Dunajski (1980) (14), a peculiarity of fish muscles is the low content of connective tissue, which explains the easy decomposition of fish meat when heated. Jasra et al. (2001) (10) report the presence of a specific enzyme called succinate dehydrogenase (succinate-coenzyme Q reductase or respiratory complex II), which can be used as a marker in the species typing of muscle fibers because it exhibits different action in red and white fibers.

\section{Freezing and thawing of fish}

Water in foodstuffs occurs in free and bound form. Reducing the water content slows down the growth of microorganisms, slows down enzymatic processes and changes in colour. When frozen, water turns to ice and cannot be used in biochemical reactions. Fish contains $75-80 \%$ water and begins to freeze at temperatures between $-1{ }^{\circ} \mathrm{C}$ and $-3{ }^{\circ} \mathrm{C}$. Most of it turns into ice between $-1{ }^{\circ} \mathrm{C}$ and $-5{ }^{\circ} \mathrm{C}$, but $90-95 \%$ freezes at $-25^{\circ} \mathrm{C}(17)$.

Matsumoto (1980) (18) defines freezing as an important method for fish storage, which results in delayed autolysis and decay. Negative effects of freezing include increased loss of water, changes in aroma and taste and soft consistency. When meat that had been frozen and thawed is cooked, unwanted texture changes such as dryness, toughness and roughness are present because its water retention and juiciness are reduced.

An indispensable benefit of applying freezing as a method is the ability to extend the shelf life of fish. The organoleptic qualities and characteristics of frozen fish may be kept close to those of fresh fish, provided that the freezing is carried out properly. This circumstance in itself creates a difficulty when it is necessary to distinguish between fresh and frozen fish. The difficulty in distinguishing is the result of the physical and chemical characteristics of fresh and thawed fish, which are close in composition and overlap to a great extent. This means that chemical and physical changes do not affect adversely fish quality (4, 19). Bacteria play a major role in fish spoilage and different technologies can be used to reduce their negative impact on fish (20). The benefit of freezing as a method of storing fish and fish products is proving to be a preferred practice due to the fact that no substances need to be used and added, and no need to be taken away from the products to be frozen (21). Gandotra et al. (2012) (22) promote the use of freezing as an appropriate method of preserving fish, as this process results in an unfavourable environment for bacteria (slows down bacterial growth and biochemical degradation) of fish muscles and thus extends the shelf life.

Freezing has its downsides as changes in muscle structure and biochemical parameters related to sensory and nutritional properties occur. The negative effects that include tissue changes and changes in lipids and proteins are 
the consequence of improper freezing and thawing $(5,23,24)$. Deterioration of fish meat quality cannot be avoided during frozen storage and therefore frozen fish must be of good quality (25).

It is not possible to detect differences in fish frozen for 1 hour and 8 hours, but when 12 hours are exceeded, the difference may become apparent. Freezing time up to 24 hours or even longer may result in lower product quality (25). Popelka et al. (2014) (26) report that muscle structure changes during freezing and storage in frozen state. The reason is the contraction of muscle fibers as a result of the movement of water into the extracellular spaces. Therefore, frozen fish are less able to retain water during thawing. Thawing, freezing and subsequent storage may reduce mechanical resistance, making fish muscles more susceptible to deterioration during processing.

Fish freshness is the most important indicator in assessing its quality. The indicators that are emphasized in judging quality are smell, aroma, taste, texture (27). The term "quality" has different meanings, but most often refers to the appearance and freshness or the degree of spoilage that the fish has undergone. It may also include safety aspects such as not containing pathogenic bacteria, parasites or chemical contaminants (17). Fish has the best quality in the first few hours after the catch. However, fresh fish in the rigor mortis condition is difficult to fillet and unsuitable for smoking and it is better to use fish that have passed the rigor mortis (28). According to Reineccius (1991) (29), the designation of a food as unacceptable for consumption is affected by its bad odour. It can be caused by various contaminants entering the food through packaging, chemicals, water, air.

Freezing plays an important role in food preservation and rapid freezing technologies are of great benefit to the food industry (30). According to Pham (2008) (31), meat freezes at about $1{ }^{\circ} \mathrm{C}$ because of the dissolved salts in it. Freezing is a widely used method of preserving meat. Various methods of freezing applied in practice have been described in literature. Tunnel freezing and cryogenic freezing are described as traditional methods. Some new food freezing technologies including high-pressure freezing (HPF), ultrasound-assisted freezing (UAF), electrically disturbed freezing (EF), magnetically disturbed freezing (MF),
STRATEVA M., et al. microwave-assisted freezing (MWF) and osmo-dehydro-freezing (ODF) have also found application $(30,32,33)$. The use of innovative freezing technologies such as HPF and UAF results in even distribution of ice crystals and control of their size and shape.

Freezing can be quick and slow. Slow freezing leads to poor product quality. This is due to the temperature-dependent denaturation of proteins. As temperature decreases, the rate of denaturation decreases. Denaturation also depends on the concentration of enzymes and other compounds present. Water freezes as pure ice crystals. The higher concentration of compounds in the non-frozen part leads to an increase in the rate of denaturation (25).

According to Pham (2008) (31), slow freezing of meat does not result in the formation of intracellular ice crystals. The structure of the meat is shrunk and dehydrated because extracellular ice crystals form. Slow freezing at higher temperatures causes more changes. Rapid freezing produces intracellular ice crystals, which are numerous and small in size. Their occurrence is directly related to faster freezing rates. If the freezing rate is reduced, one or more large crystals will form intracellularly. Jiang et al. (2018) (34) reported the formation of a large number of nuclei limiting the size of ice crystals at high freezing rates. Ultrarapid freezing in liquid nitrogen can cause muscle fibers to crack. This will accelerate the microstructural deterioration and decrease of fish meat quality. Chevalier et al. (2000) (35) found that the size of ice crystals was significantly smaller during rapid freezing and had less distribution in muscles. Syamaladevi et al. (2012) (36) reported larger sizes of ice crystals with increasing the storage temperature. This is probably due to the increased mobility of water at high storage temperatures. According to Grujić et al. (1993) (37) an increase in the freezing rate leads to a change in the location of the ice crystals. Another author found that the crystal size was formed in the temperature range between $0{ }^{\circ} \mathrm{C}$ and $-5{ }^{\circ} \mathrm{C}$ (38). The formation of ice crystals during freezing damages the ultrastructure and concentrations of various substances in meat, thus resulting in biochemical changes on cellular level and physical changes accounting for meat quality (39). 
Histological characteristics of fresh and frozen/thawed fish

Histological examination is a reliable means of distinguishing between fresh and frozen and then thawed fish (40). Freezing speed and storage conditions affect muscle structure. The distance between muscle fibers of fish frozen in liquid nitrogen is less than that of fish shock frozen in a tunnel. During frozen storage, the distance between muscle fibers is increased, suggesting that storage conditions have a greater effect than freezing rate (41). Gambuteanu et al. (2013) (42) demonstrated strong damage to muscle fibers from the formation of ice crystals between the fibers, resulting in their separation. The ice crystals formed inside the fibers disrupt the integrity of muscle fibers to a lesser extent. According to Ngapo et al. (1999) (43) in the freezing process of fresh meat the intercellular fluid freezes first. The structure of frozen meat is estimated by the size of the voids formed, which correspond to the size of the ice crystals.

The histological finding in the study of fresh (chilled) fish did not indicate any changes in the endomysium and perimysium of muscle fibers and tufts. The fibers are with retained integrity without any disruption or damage. There is no noticeable difference between individual fibers and bundles. Myofibrils are tightly bound. No histological changes are observed in the different sections of muscles. Changes or minor alterations in the microstructure may occur, resulting from the processing and action of the retainer during sample preparation, and may be classified as artifacts $(26,44)$.

Li et al. (2018) (45) report damage to cellular structures after freezing. They are expressed in depolymerization and destruction of the cell membrane, changes in osmotic pressure and damage to tissue and cellular structures. According to Nieto (2004) (46), under the influence of osmotic pressure, tissue shrinkage occurs as a result of folding the cell wall, cleavage of its lamellae and widening the intercellular spaces.

According to Zhang et al. (2019) (47), the growth of ice crystals in frozen muscle is determined by microscopic observation of microstructural changes in the muscle tissue. Scanning electron microscopy reveals large gaps in the microscopic image of frozen/thawed tissue, separation of myofibrils, and formation with numerous small fragments.
The space between myofibrils is considerably increased compared to fresh tissue. Ice crystals form during single freezing of muscles. These crystals can increase in size as temperatures rise during storage and come into contact with other crystals. In this way, their volume is increased and the muscles are distorted. Sánchez-Valencia et al. (2014) (48) demonstrated changes in the organization of myofibrils and changes in the functional properties of frozen hake muscles (Merluccius merluccius), which involve different conformations of actin and myosin proteins.

Less muscle damage occurs with rapid freezing compared to slow freezing. Slow freezing causes major structural damage to muscle fibers as a result of the pressure of large ice crystals between muscle fibers. Large gaps between muscle fibers in frozen/thawed meat are observed due to shrinkage of fibers and rupture of endomysium (49). Melody et al. (2004) (50) consider that proteolysis of cytoskeletal proteins results in swelling of muscle cells and thus more water is incorporated into their structure. Therefore, cellular swelling by endogenous proteolysis during storage of meat is associated with the appearance of tight gaps between muscle fibers in frozen/thawed samples.

Muscles frozen at $-20{ }^{\circ} \mathrm{C}$ for 142 min show larger ice crystals in the intercellular spaces than muscles frozen $-78^{\circ} \mathrm{C}$ for $8.2 \mathrm{~min}$ (37). Rahelić (1985) (51) proved that in muscle tissue frozen at $-22{ }^{\circ} \mathrm{C}$ for $336 \mathrm{~min}$ there were intracellular and intracellular ice crystals, while muscles frozen at $-78{ }^{\circ} \mathrm{C}$ for $10 \mathrm{~min}$ showed intracellular ice crystals only.

Pavlov et al. (2008) (44) performed histological and morphometric studies of fresh and frozen/thawed carp (Cyprinus carpio) without detecting any changes in fresh samples. In frozen and thawed specimens, changes in the structure of muscle tissue were observed and there were decay processes in the muscle cells in the central part, but the periphery was preserved. The borders and shape of these cells were well visible and easily distinguishable due to the wellpreserved endomysium.

Tinacci et. al. (2018) (5) offer morphological features that can be used to histologically distinguish fresh from frozen and thawed hake (Merluccius merluccius). These characteristics include degrees of muscle breakdown, 
vacuolation, and the establishment of protein material. Muscle changes are graded as complete or partial destruction or wellpreserved muscle. Bozzetta et al. (2012) (52) also consider as a major indicator related to freezing the presence of vacuoles in the intracellular space of muscle fibers. Solid texture of fish meat caused by shrinkage of myofibrillar units by ice crystals during freezing is demonstrated by Yoon et al. (1991) (53).

According to Kiani and Sun (2011) (54) the use of slow freezing methods leads to osmotic phenomena, dehydration and shrinkage of fibers. Large extracellular crystals are formed and cell membranes are ruptured. In support of this claim, Tinacci et al. (2018) (5) prove that shock freezing in a tunnel at $-35^{\circ} \mathrm{C}$ to $-45^{\circ} \mathrm{C}$ for 1 to 3 hours preserves muscle structure better than conventional freezing at $-20{ }^{\circ} \mathrm{C}$ for 15 days in a freezer.

Muscle fibers of fresh fish Channa argus studied by Jiang et al. (2018) (34) show a polygonal shape by being firmly attached to each other. The cell boundaries are distinct and no breaks are observed between cells. Frozen fish show deformed and damaged myofibrils, greater extracellular space and major cellular damage. Popelka et al. (2014) (26) studied the histological changes in rainbow trout (Oncorhynchus mykiss) after freezing. Fresh fish had minimal variations in microstructural changes caused by sample processing. In frozen and thawed fish, defects in the muscle structure were detected in the empty areas along muscle fibers. In addition, sites with muscle fiber and epimysium disruption have also been observed. The muscle fiber structure is completely destroyed in double frozen trout.

The effect of freezing salmon (Salmo salar) on the transverse microstructure of fillets is mainly expressed in the extended extracellular space among fibers. Frozen and defrosted fish show broken and shrunk cells, while fresh fish lack cracks (55).

Shi et al. (2018) (56) reported microstructural changes during freezing of Largemouth black bass (Micropterus salmoides). The same cellular spaces were observed in fresh and frozen fish with liquid nitrogen. In frozen and thawed fish shrinkage of the intracellular and expansion of the extracellular space were found.
Microstructural changes in European seabass (Dicentrarchus labrax) frozen in a tunnel at $30{ }^{\circ} \mathrm{C}$ for 2 hours at an air speed of $4 \mathrm{~m} / \mathrm{s}$ and subsequently stored for 3 months at $-15{ }^{\circ} \mathrm{C}$ and $-25{ }^{\circ} \mathrm{C}$ have been reported by Tironi (2010) (57). Highly deformed and contracted muscle fibers and large intra- and extracellular ice crystals have been identified. There is no shrinkage of cells, but changes in their shape due to extracellular ice have been observed.

According to Doughikollaee (2012) (58) ice crystals formed strongly affect the structure of muscle tissue. Freezing in a tunnel at low speed $(1.62 \mathrm{~cm} / \mathrm{h})$ results in significant cell shrinkage and formation of large extracellular ice crystals. Intra- and extracellular ice crystals were observed during freezing in a high-speed $(2.51 \mathrm{~cm} / \mathrm{h})$ freezing tunnel.

\section{Physicochemical characteristics of fresh and frozen/thawed fish}

Lipids are the third major component in the physicochemical composition of fish after water and proteins. In fish muscle, lipids consist of triacylglycerol and phosphoglycerides, which contain long-chain fatty acids. Lipid content varies among species, with differences depending on the type of muscle and its location, age, sex and sexual maturity (17). Ramalhosa et al. (2012) (59) reported poor quality of fish meat caused by lipid hydrolysis and oxidation.

According to Jasra et al. (2001) (10) the nutritional value of fish is irreplaceable and incomparable due to its lipid composition. Polyunsaturated fatty acids (PUFA) predominate. This class contains essential fatty acids in their role as components involved in a balanced diet. Known representatives are eicosapentaenoic and docosahexaenoic acids, thanks to these fatty acids, fish meat increases its nutritional value because omega-3 fatty acids are indispensable for human health (60, 61). Dong et al. (2017) (6) classify fish according to lipid content as lean fish $(<2 \%)$, low fat fish (2-4\%), average fat fish (4-8\%) and lastly those with high amounts of lipids (>8\%). Common carp (Cyprinus carpio) is defined as low fat fish (2-4\%). According to Gokoglu and Yerlikaya (2015) (17), fish is classified as lean $(<5 \%)$, semi-fat $(5-10 \%)$ and fat $(>10 \%)$.

Hydrolysis of fat, which decomposes to free fatty acids, occurs as an adverse side effect during storage of fish. The cause of this 
phenomenon is cellular decay induced by frozen storage (24). Pirestani et al. (2010) (62) proved that the storage period had an effect on the quality of fat. According to authors, longterm storage is unfavourable in terms of quality composition of fatty acids, which leads to a loss of nutritional value of fish meat. This is mainly due to the losses covering the polyunsaturated fatty acids group.

Proteins are complex sets of polymers made up of 21 different aminoacids linked through amide bonds. Proteins differ in their nutritional value. The functional diversity of proteins arises from their chemical composition. Highquality proteins are those that contain all major aminoacids at levels greater than reference levels (63).

Gokoglu and Yerlikaya (2015) (17) determined that the red fish muscle had darker appearance due to the high myoglobin concentration. Myoglobin content in muscles increases with age. Oxymyoglobin and oxyhemoglobin are responsible for the colour characteristics of the fish muscle. During storage, haemoglobin is easily dissolved while myoglobin is retained in the cellular structure. These structures relate to sarcoplasmic proteins. Myofibrillar proteins are structural proteins that make up $65-70 \%$ of the fish muscle protein. The proportion of myofibrillar protein in total muscle protein is higher in fish than in terrestrial animals. Gokoglu and Yerlikaya (2015) (17) further added that myosin and actin exist as an actomyosin complex during post-mortem processes. Fish actomyosin has been found to be labile and easy to change during processing and storage. During frozen storage, actomyosin becomes firmer. Fish myosin is unstable as it is more sensitive to denaturation, coagulation, degradation.

Myoglobin is localized in red muscle fibers and its concentration and stability depend on a number of factors. One is these is the way meat is processed. As for myoglobin activity, it depends on the storage period (64). In addition, changes in the colour of meat result from the reaction of myoglobin with the myofibrillar proteins actin and myosin. According to Jeong et al. (2011) (65), the change in the color of meat is also due to the brown metmyoglobin resulting from the oxidation of oxymyoglobin. Leygonie et al. (2012) (39) explained that in protein denaturation, the possibility of autooxidation of myoglobin increases, which is thought to be a cause of discoloration of meat.
Proteins are considered to be a major component of muscle tissue (66).

Loss of proteins and their functionality in fish is the result of frozen storage, which leads to poor quality of fish meat. In addition, storage temperature is a factor responsible for the destabilization of the protein and lipid composition and the associated degradation of myofibrillar proteins. This is closely related to the demethylation of trimethylamine oxide (67).

\section{Microbiological characteristics of fresh and frozen/thawed fish}

Fish is one of the most perishable food products and its spoilage is due to the action of enzymes secreted by microorganisms. Bacteria on the skin, gills, and intestines are usually harmless to living fish, but they begin to multiply rapidly after death. The skin, gills and intestines of clean water fish usually contain a large number of microorganisms, and the muscles are considered sterile. Fish can be contaminated after being caught or during transportation to stores for marketing. After contamination and development of microorganisms, processes of spoilage occur and the consumption of these products becomes dangerous. The quality of fish is influenced by numerous factors such as raw materials, cooling methods, processing, packaging and storage conditions. The quality and freshness of fish deteriorate rapidly due to microbial and biochemical mechanisms. Bacterial activity results in unpleasant odour changes due to the conversion of aminoacids into biogenic amines, sulfides, organic acids and other ingredients (68). Therefore, reducing the bacterial count by various methods such as cleaning and washing can extend the shelf life (20).

Effective hygiene control through bacteriological examination is important to ensure acceptable levels of contamination and avoid adverse effects on human health (69). The type and number of microorganisms in frozen fish depends on the origin of fish. Further contamination may occur after the catch during processing and storage. A source of contamination may also be fish workers and traders. Fish can be a source of pathogenic bacteria, which is why heat treatment before consumption is recommended (70). Freezing affects bacteria and their growth in fish by freezing microorganisms and dying as a result of cell dehydration. Freezing rate, storage 
STRATEVA M., et al.

temperature, and temperature fluctuations during storage affect the degree of cellular damage of microorganisms. Thawing also affects the bacteria present in fish and after thawing the microbial population decreases (71). Akhtar et al. (2013) (72) believed that freezing reduces the bacterial count in meat. During freezing microorganisms are inhibited, which extends the shelf life. According to Zhao et al. (2017) (73) microbiological analysis is one of the most important tools for assessing fish freshness. The activity of microorganisms is a major factor reducing the shelf life of fresh fish. According to Gandotra et al. (2012) (22) microbial activity can lead to strong odour in fish, resulting in short shelf life and subsequent economic losses. Yagoub (2009) (74) believed that marketing raw fish can be a source of pathogenic bacteria and therefore appropriate treatment to minimize their spread is required. Microorganisms of the Enterobacteriaceae family are hygienic and suggest the need to improve the hygiene of the production process.

Geiges (1996) (75) stated that lipases and proteases are active at $-18{ }^{\circ} \mathrm{C}$. Stratev et al. (2015) (68) reported that microbial enzymes led to fish spoilage. According to Shamsuzzaman et al. (2011) (76) and Stratev et al. (2015) (68) the activity of microbial enzymes can be minimized when hygiene rules are observed in processing. The quality of frozen fish depends on the total aerobic bacterial count and those relevant to public health. The International Committee on Microbiological Specifications for Foods limits the total aerobic microorganisms count to 7 $\log \mathrm{cfu} / \mathrm{g}$ for fresh and frozen fish (77). According to Geiges (1996) (75), the lower bacterial growth limit in food is from $-5{ }^{\circ} \mathrm{C}$ to $-8^{\circ} \mathrm{C}$ and storage temperatures above $-10^{\circ} \mathrm{C}$ should not be used. The author adds that at -18 ${ }^{\circ} \mathrm{C}$, the temperature at which frozen fish is stored, no growth of microorganisms is observed. According to Uddin et al. (2013) (78) improper storage and handling of fish could lead to increased bacterial growth of species causing spoilage such as Pseudomonas, Lactobacillus, Proteus, Shewanella putrefaciens. Akhtar et al. (2013) (72) added that thawing was a much slower process than freezing. It is less uniform and certain parts of the meat will be exposed to more favourable temperature conditions for growth of microorganisms. This is especially important when air defrosting is used. In addition to the risk of heat exposure, there is an increase in the moisture and nutrients available to microorganisms after freezing and thawing. Opoku-Nkoom (2015) (79) also supported the view that some microorganisms survived freezing temperatures by hibernation and, under favourable conditions, they could regain viability. Ideally, freezers should operate at temperatures of $-18{ }^{\circ} \mathrm{C}$ and below. At higher temperatures, for example $-5{ }^{\circ} \mathrm{C}$ to $-10{ }^{\circ} \mathrm{C}$, which could occur during power outage, some psychrotrophic microorganisms can still grow and cause changes in food.

Chytiri et al. (2004) (80) examined the bacterial composition of rainbow trout (Onchorynchus mykiss) stored in ice and isolated Pseudomonas, Shewanella putrefaciens and Brochothrix thermosphacta as dominant bacteria, whereas Enterobacteriaceae was in lower numbers. The number of mesophilic bacteria exceeded $7 \log$ $\mathrm{cfu} / \mathrm{cm}^{2}$ after 10 and 18 days of storage.

Rezaei and Hosseini (2008) (81) determined the total number of microorganisms in rainbow trout (Onchorynchus mykiss) stored in ice for 20 days. On the first day of storage, their number was $4.0 \log \mathrm{cfu} / \mathrm{g}$, and on the 20th day of storage they were $7.04 \log \mathrm{cfu} / \mathrm{g}$. The shelf life of rainbow trout stored in ice is 9 to 11 days. Gobantes et al. (1998) (82) demonstrated that the shelf life of rainbow trout fillets (Onchorynchus mykiss) stored in a vacuum package at $4{ }^{\circ} \mathrm{C}$ is 5 days.

Al-Jasser and Al-Jasass (2014) (83) conducted a microbiological study of fresh Narrow-barred Spanish mackerel (Scomberomorous commerson) stored at $4{ }^{\circ} \mathrm{C}$ and $7{ }^{\circ} \mathrm{C}$ for 6 days and frozen at $-10^{\circ} \mathrm{C}$ and $-18^{\circ} \mathrm{C}$ for 6 months. The total number of microorganisms and coliforms during cooling were 4.6 and $3.3 \mathrm{log}$ $\mathrm{cfu} / \mathrm{g}$, respectively. The shelf life at $4{ }^{\circ} \mathrm{C}$ is 6 days and at $7{ }^{\circ} \mathrm{C}$ it is 3 days.

Liu et al. (2014) (84) studied the effect of refrigerated storage on the microbial growth of common carp (Cyprinus carpio). It was found that with increasing storage time the microbial count increased from day one $(4.4 \mathrm{log} \mathrm{cfu} / \mathrm{g})$ to 35 days at $-1{ }^{\circ} \mathrm{C}(7.2 \log \mathrm{cfu} / \mathrm{g}),-3{ }^{\circ} \mathrm{C}(6,2$ $\log \mathrm{cfu} / \mathrm{g}),-3{ }^{\circ} \mathrm{C}$ with cryoprotectants $(5.9 \log$ $\mathrm{cfu} / \mathrm{g})$ and $-18{ }^{\circ} \mathrm{C}(5.5 \log \mathrm{cfu} / \mathrm{g})$.

Stratev et al. (2015) (68) reported values for chilled and frozen fish fillets of rainbow trout (Onchorynchus mykiss) and common carp (Cyprinus carpio). The chilled trout contains $7.11 \log \mathrm{cfu} / \mathrm{g}$, the chilled carp $6.81 \mathrm{log} \mathrm{cfu} / \mathrm{g}$, 
and the frozen trout $4.27 \log \mathrm{cfu} / \mathrm{g}$. Li et al. 2016 (15) showed a different number of bacteria in the white $(3.71 \log \mathrm{cfu} / \mathrm{g})$ and red (3.27 log cfu/g) muscle fibers of common carp (Cyprinus carpio) stored in the refrigerator. $\mathrm{Hu}$ et al. (2010) (85) reported that the total icroorganism count in common carp (Cyprinus carpio) stored at $4{ }^{\circ} \mathrm{C}$ for 12 days was $5.67 \log$ $\mathrm{cfu} / \mathrm{g}$, and for stored at $-3{ }^{\circ} \mathrm{C}$ for 40 days it was $5.72 \log \mathrm{cfu} / \mathrm{g}$.

Taşkaya et al. (2003) (86) froze at $-35{ }^{\circ} \mathrm{C}$ the rainbow trout fillets (Onchorynchus mykiss) and stored them at $-24{ }^{\circ} \mathrm{C}$ for 3 months. The total microorganism count for fresh fish is 7.48 $\log \mathrm{cfu} / \mathrm{g}$ and for frozen and thawed fish it is $5.58 \mathrm{log} \mathrm{cfu} / \mathrm{g}$. Coliform bacteria count in fresh fillets is greater than the count in fillet from frozen and thawed rainbow trout.

Adebayo-Tayo et al. (2012) (69) reported values for total microorganism count in frozen Frigate tuna (Auxis thazard) (from 3.0 to $4.8 \mathrm{x}$ $10^{5} \mathrm{cfu} / \mathrm{g}$ ), Bonga shad (Ethmalosa fimbriata) (from 3.0 to $4.8 \times 10^{5} \mathrm{cfu} / \mathrm{g}$ ) and Atlantic mackerel (Scomber scombrus) (from 3.0 to 6.3 $\left.\mathrm{x} 10^{5} \mathrm{cfu} / \mathrm{g}\right)$. The total coliform count in the three fish species are 2-4 x $10^{5} \mathrm{cfu} / \mathrm{g}, 2.5-3.9 \mathrm{x}$ $10^{5} \mathrm{cfu} / \mathrm{g}$ and $2-6 \times 10^{5} \mathrm{cfu} / \mathrm{g}$, respectively.

Arannilewa et al. (2005) (87) studied the total coliform count in Mango tilapia (Sarotherodun galiaenus). In fresh fish, the values are $3 \times 10^{3}$ $\mathrm{cfu} / \mathrm{g}$ and in frozen fish, they are $7.5 \times 10^{6}$ $\mathrm{cfu} / \mathrm{g}$ after 60 days of storage.

\section{CONCLUSION}

The supply of frozen and thawed fish as fresh fish for human consumption should be considered a fraudulent practice since quality is considerably deteriorated in such processing. Significant changes in the histostructure, physicochemical and microbiological parameters of fish muscle tissue are observed. Freezing causes damage to cellular structures, expansion of the intercellular spaces, large voids between muscle fibers, contraction of muscle fibers, and destruction of muscle tissue. Protein denaturation and fat hydrolysis result from frozen fish storage. Freezing temperatures inhibit the bacteria present, making them less when isolated from frozen fish. Histological examination is a reliable method of distinguishing between fresh and frozen and thawed fish.

\section{REFERENCES}

1. FAO, The State of World Fisheries and Aquaculture. FAO, Rome, 2016.

2. Regulation EU No 1169/2011 Of the european parliament and of the council of 25 october 2011 on the provision of food information to consumers, amending regulations (EC) No 1924/2006 and (EC) No 1925/2006 of the european parliament and of the council, and repealing commission directive 87/250/EEC, council directive 90/496/EEC, commission directive 1999/10/EC, directive 2000/13/EC of the european parliament and of the council, commission directives 2002/67/EC and 2008/5/EC and commission regulation (EC) No 608/2004. Official Journal of the European Union, L 304, 18-63.

3. Regulation EU No 1379/2013 Of the European Parliament and of the Council of 11 December 2013 on the common organisation of the markets in fishery and aquaculture products, amending Council Regulations (EC) No 1184/2006 and (EC) No 1224/2009 and repealing Council Regulation (EC) No 104/2000. Official Journal of the European Union, L 354, 121.

4. Karoui, R., Thomas, E., and Dufour, E., Utilisation of a rapid technique based on front-face fluorescence spectroscopy for differentiating between fresh and frozenthawed fish fillets. Food Res Int, 39:349355, 2006.

5. Tinacci, L., Armani, A., Guidi, A., Nucera, D., Shvartzman, D., Miragliotta, V., ... and Di Iacovo, F., Histological discrimination of fresh and frozen/thawed fish meat: European hake (Merluccius merluccius) as a possible model for white meat fish species. Food Control, 92:154-161, 2018.

6. Dong, X. P., Wu, Q., Li, D. Y., Wang, T., Pan, J. F., Zheng, J. J., ... and Chen, G. B., Physicochemical, micro-structural, and textural properties of different parts from farmed common carp (Cyprinus carpio). Int J Food Prop, 20:946-955, 2017.

7. Mokhtar, D. M., Fish Histology: From Cells to Organs, 1 edn, Apple Academic Press Inc, 2017.

8. Delos, D., Maak, T. G., and Rodeo, S. A., Muscle injuries in athletes: enhancing recovery through scientific understanding and novel therapies. Sports Health, 5:346352, 2013.

9. Bach, A. D., Beier, J. P., Stern- Staeter, J., and Horch, R. E., Skeletal muscle tissue 
STRATEVA M., et al.

engineering. J Cell Mol Med, 8:413-422, 2004.

10.Jasra, S. K., Jasra, P. K., and Talesara, C. L., Myofibrillar protein degradation of carp (Labeo rohita (Hamilton)) muscle after post- mortem unfrozen and frozen storage. J Sci Food Agric,81:519-524, 2001.

11.Ayala, M. D., Albors, O. L., Blanco, A., Alcázar, A. G., Abellán, E., Zarzosa, G. R., and Gil, F., Structural and ultrastructural changes on muscle tissue of sea bass, Dicentrarchus labrax L., after cooking and freezing. Aquaculture, 250:215-231, 2005.

12.Genten, F., Atlas of Fish Histology. CRC Press, 2009.

13.Kaale, L. D., and Eikevik, T. M., A study of the ice crystal sizes of red muscle of prerigor Atlantic salmon (Salmo salar) fillets during superchilled storage. $J$ Food Eng, 119:544-551, 2013.

14.Dunajski, E., Texture of fish muscle. $J$ Texture Stud, 10:301-318, 1980.

15.Li, Q., Li, D., Qin, N., Hong, H., and Luo, Y., Comparative studies of quality changes in white and dark muscles from common carp (Cyprinus carpio) during refrigerated $\left(4{ }^{\circ} \mathrm{C}\right)$ storage. Int $J$ Food $\mathrm{Sci}$ Tech, 51:1130-1139, 2016.

16.Karahmet, E., Vileš, A., Katica, A., Mlaćo, N., and Toroman, A., Differences between white and red muscle fibers diameter in three salmon fish species. Biotechnol Anim Husb, 30:349-356, 2014.

17.Gokoglu, N., Yerlikaya, P., Seafood chilling, refrigeration and freezing: science and technology. John Wiley \& Sons, 2015.

18. Matsumoto, J. J., Chemical deterioration of muscle proteins during frozen storage. Chemical Deterioration of Proteins, 123:95-124, 1980.

19.Uddin, M., Differentiation of Fresh and Frozen-Thawed Fish. In: Nollet LM, Toldrá F (eds), Handbook of seafood and seafood products analysis. CRC Press, 2009.

20.Sterniša, M., Mraz, J., and Možina, S. S., Microbiological aspects of common carp (Cyprinus carpio) and its processingrelevance for final product quality: a review. Aquacult Int, 24:1569-1590, 2016.

21.Pavlov, A., Changes in the meat from aquaculture species during storage at low temperature and attempts for differentiation between thawed-frozen and fresh chilled meat. A review. Bulg J Vet Med, 10:67-75, 2007.
22.Gandotra, R., Koul, M., Gupta, S., and Sharma, S., Change in proximate composition and microbial count by low temperature preservation in fish muscle of Labeo rohita (Ham-Buch). IOSR J Pharm Biol Sci, 2:13-17, 2012.

23.Velioğlu, H. M., Temiz, H. T., and Boyaci, I. H., Differentiation of fresh and frozenthawed fish samples using Raman spectroscopy coupled with chemometric analysis. Food Chem, 172:283-290, 2015.

24.Makri, M., Full Length Research Paper Biochemical and textural properties of frozen stored $\left(-22{ }^{\circ} \mathrm{C}\right)$ gilthead seabream (Sparus aurata) fillets. Afr J Biotechnol, 8, 2009.

25.FAO and WHO, Code of Practice for Fish and Fishery Products, second ed. FAO and WHO, Rome, 2012

26.Popelka, P., Nagy, J., Pipová, M., Marcinčák, S., and Lenhardt, L., Comparison of chemical, microbiological and histological changes in fresh, frozen and double frozen rainbow trout (Oncorhynchus mykiss). Acta Vet Brno, 83:157-161, 2014.

27.Alasalvar, C., Taylor, K. D. A., Öksüz, A., Garthwaite, T., Alexis, M. N., and Grigorakis, K., Freshness assessment of cultured sea bream (Sparus aurata) by chemical, physical and sensory methods. Food Chem, 72:33-40, 2001.

28.Huss, H. H. (Ed.)., Quality and quality changes in fresh fish (Vol. 348). Rome: FAO, 1995

29. Reineccius, G., Off- flavors in foods. Crit Rev Food Sci Nutr, 29:381-402, 1991.

30.Cheng, L., Sun, D. W., Zhu, Z., and Zhang, Z., Emerging techniques for assisting and accelerating food freezing processes: A review of recent research progresses. Crit Rev Food Sci Nutr, 57:769-781, 2017.

31.Pham, Q. T., Advances in food freezing/thawing/freeze concentration modelling and techniques. Japan J Food Eng, 9:21-32, 2008.

32.Zhan, X., Sun, D. W., Zhu, Z., and Wang, Q. J., Improving the quality and safety of frozen muscle foods by emerging freezing technologies: A review. Crit Rev Food Sci Nutr, 58:2925-2938, 2018.

33.Knorr, D., Froehling, A., Jaeger, H., Reineke, K., Schlueter, O., and Schoessler, $\mathrm{K}$., Emerging technologies in food processing. Annu Rev Food Sci T, 2, 203235, 2011. 
34.Jiang, Q., Okazaki, E., Zheng, J., Que, T., Chen, S., and $\mathrm{Hu}$, Y., Structure of northern snakehead (Channa argus) meat: Effects of freezing method and frozen storage. Int $J$ Food Prop, 21:1166-1179, 2018.

35. Chevalier, D., Sequeira-Munoz, A., Le Bail, A., Simpson, B. K., and Ghoul, M., Effect of freezing conditions and storage on ice crystal and drip volume in turbot (Scophthalmus maximus): evaluation of pressure shift freezing vs. air-blast freezing. Innov Food Sci Emerg Technol, 1:193-201, 2000.

36.Syamaladevi, R. M., Manahiloh, K. N., Muhunthan, B., and Sablani, S. S., Understanding the influence of state/phase transitions on ice recrystallization in Atlantic salmon (Salmo salar) during frozen storage. Food Biophys, 7:57-71, 2012.

37.Grujić, R., Petrović, L., Pikula, B., and Amidžić, L., Definition of the optimum freezing rate-1. Investigation of structure and ultrastructure of beef $M$. longissimus dorsi frozen at different freezing rates. Meat Sci, 33:301-318, 1993.

38. Miyawaki, O., Analysis and control of ice crystal structure in frozen food and their application to food processing. Food Sci Technol Res, 7:1-7, 2001.

39.Leygonie, C., Britz, T. J., and Hoffman, L. C., Impact of freezing and thawing on the quality of meat. Meat Sci, 91:93-98, 2012.

40.Meistro, S., Pezzolato, M., Muscolino, D., Giarratana, F., Baioni, E., Panebianco, A., et al., Histology as a valid tool to differentiate fresh from frozen-thawed marinated fish. J Food Prot, 79:1457-1459, 2016.

41.Shahidi, F., Botta, J. R., Seafoods: chemistry, processing technology and quality. Springer Science \& Business Media, 2012.

42.Gambuteanu, C., Borda, D., and Alexe, P., The effect of freezing and thawing on technological properties of meat. $J$ Agroaliment Proc Technol, 19:88-93, 2013.

43.Ngapo, T. M., Babare, I. H., Reynolds, J., and Mawson, R. F., Freezing rate and frozen storage effects on the ultrastructure of samples of pork. Meat Sci, 53:159-168, 1999.

44.Pavlov, A., Dimitrov, D., Penchev, G., and Georgiev, L., Structural changes in common carp (Cyprinus carpio L.) fish meat during freezing. Bulg $J$ Vet Med, 11:131-136, 2008.
45.Li, D., Zhu, Z., and Sun, D. W., Effects of freezing on cell structure of fresh cellular food materials: A review. Trends Food Sci Tech, 75:46-55, 2018.

46.Nieto, A. B., Salvatori, D. M., Castro, M. A., and Alzamora, S. M., Structural changes in apple tissue during glucose and sucrose osmotic dehydration: shrinkage, porosity, density and microscopic features. J Food Eng, 61:269-278, 2004.

47.Zhang, M., Xia, X., Liu, Q., Chen, Q., and Kong, B., Changes in microstructure, quality and water distribution of porcine longissimus muscles subjected to ultrasound-assisted immersion freezing during frozen storage. Meat Sci, 151:24-32, 2019.

48.Sánchez-Valencia, J., Sánchez-Alonso, I., Martinez, I., and Careche, M., Estimation of frozen storage time or temperature by kinetic modeling of the Kramer shear resistance and water holding capacity (WHC) of hake (Merluccius merluccius, L.) muscle. J Food Eng, 120:37-43, 2014.

49.Kim, H. W., Kim, J. H., Seo, J. K., Setyabrata, D., and Kim, Y. H. B., Effects of aging/freezing sequence and freezing rate on meat quality and oxidative stability of pork loins. Meat Sci, 139:162-170, 2018.

50.Melody, J. L., Lonergan, S. M., Rowe, L. J., Huiatt, T. W., Mayes, M. S., and HuffLonergan, E., Early postmortem biochemical factors influence tenderness and water-holding capacity of three porcine muscles. J Anim Sci, 82:1195-1205, 2004.

51.Rahelić, S., Puač, S., and Gawwad, A. H., Structure of beef Longissimus dorsi muscle frozen at various temperatures: Part 1histological changes in muscle frozen at $10,-22,-33,-78,-115$ and -196 C. Meat Sci, 14:63-72, 1985.

52.Bozzetta, E., Pezzolato, M., Cencetti, E., Varello, K., Abramo, F., Mutinelli, F., ... and Teneggi, E., Histology as a valid and reliable tool to differentiate fresh from frozen-thawed fish. J Food Prot, 75:15361541, 2012.

53. Yoon, K. S., Lee, C. M., and Hufnagel, L. A., Textural and microstructural properties of frozen fish mince as affected by the addition of nonfish proteins and sorbitol. Food Struct, 10:8, 1991.

54.Kiani, H., and Sun, D. W., Water crystallization and its importance to freezing of foods: A review. Trends Food Sci Tech, 22:407-426, 2011. 
55.Sigurgisladottir, S., Ingvarsdottir, H., Torrissen, O. J., Cardinal, M., and Hafsteinsson, H., Effects of freezing/thawing on the microstructure and the texture of smoked Atlantic salmon (Salmo salar). Food Res Int, 33:857-865, 2000.

56.Shi, L., Yang, T., Xiong, G., Li, X., Wang, X., Ding, A., ... and Wang, L., Influence of frozen storage temperature on the microstructures and physicochemical properties of pre-frozen perch (Micropterus salmoides). Lwt, 92:471-476, 2018.

57.Tironi, V., De Lamballerie, M., and LeBail, A., Quality changes during the frozen storage of sea bass (Dicentrarchus labrax) muscle after pressure shift freezing and pressure assisted thawing. Innov Food Sci Emerg, 11:565-573, 2010.

58.Doughikollaee, E. A., Freezing/Thawing and Cooking of Fish. Scientific, Health and Social Aspects of the Food Industry, 57-67, 2012.

59.Ramalhosa, M. J., Paíga, P., Morais, S., Alves, M. R., Delerue-Matos, C., and Oliveira, M. B. P. P., Lipid content of frozen fish: Comparison of different extraction methods and variability during freezing storage. Food Chem, 131:328-336, 2012.

60.Tenyang, N., Tiencheu, B., Tonfack Djikeng, F., Morfor, A. T., and Womeni, H. M., Alteration of the lipid of red carp (Cyprinus carpio) during frozen storage. Food Sci Nutr, 7:1371-1378, 2019.

61.Connor, W. E., Importance of n-3 fatty acids in health and disease. Am J Clin Nutr, 71:171S-175S, 2000.

62.Pirestani, S., Saharian, M., and Barzegar, M., Fatty acids changes during frozen storage in several fish species from South Caspian Sea. J Agr Sci Tech, 12:321-329, 2010.

63.Fennema, O. R., Fennema's food chemistry. CRC press, 2008.

64.Chaijan, M., Benjakul, S., Visessanguan, W., and Faustman, C., Changes of pigments and color in sardine (Sardinella gibbosa) and mackerel (Rastrelliger kanagurta) muscle during iced storage. Food Chem, 93:607-617, 2005.

65.Jeong, J. Y., Kim, G. D., Yang, H. S., and Joo, S. T., Effect of freeze-thaw cycles on physicochemical properties and color stability of beef semimembranosus muscle. Food Res Int, 44:3222-3228, 2011.
66.Nathan, S., Chowdhury, M. E. H., Anuar, Z. M. Z., Iekhsan, O., Sharifah, S. H., and Ahmed, N., Protein thaw loss in meat systems: biochemical influence towards meat authentication of fresh versus thawed. Int Food Res J, 23:1857-1864, 2016.

67.Namulema, A., Muyonga, J. H., and Kaaya, A. N., Quality deterioration in frozen Nile perch (Lates niloticus) stored at -13 and $27^{\circ}$ C. Food Res Int, 32:151-156, 1999.

68.Stratev, D., Vashin, I., and Daskalov, H., Microbiological status of fish products on retail markets in the Republic of Bulgaria. Int Food Res J, 22:64, 2015.

69.Adebayo-Tayo, B. C., Odu, N. N., Anyamele, L. M., Igwiloh, N. J. P. N., and Okonko, I. O., Microbial quality of frozen fish sold in Uyo Metropolis. Nat Sci, 10:7177, 2012.

70.Eze, E. I., Echezona, B. C., and Uzodinma, E. C., Isolation and identification of pathogenic bacteria associated with frozen mackerel fish (Scomber scombrus) in a humid tropical environment. Afr J Agric Res, 6:1947-1951, 2011.

71.Hempel, A., Borchert, N., Walsh, H., Choudhury, K. R., Kerry, J. P., and Papkovsky, D. B., Analysis of total aerobic viable counts in raw fish by highthroughput optical oxygen respirometry. $J$ Food Prot, 74:776-782, 2011.

72.Akhtar, S., Khan, M. I., and Faiz, F., Effect of thawing on frozen meat quality: A comprehensive review. Pak $J$ Food Sci, 23:198-211, 2013.

73.Zhao, Y., Yang, X., Li, L., Hao, S., Wei, Y., Cen, J., and Lin, H., Chemical, microbiological, color and textural changes in Nile Tilapia (Oreochromis niloticus) fillets sterilized by ozonated water pretreatment during frozen storage. J Food Process Pres, 41:12746, 2017.

74. Yagoub, S. O., Isolation of Enterobacteriaceae and Pseudomonas spp. from raw fish sold in fish market in Khartoum state. J Bacteriol Res, 1:085-088, 2009.

75.Geiges, O., Microbial processes in frozen food. Adv Space Res, 18:109-118, 1996.

76.Shamsuzzaman, M. M., Mazumder, S. K., Siddique, M. A., and Miah, M. N. U., Microbial quality of hilsa shad (Tenualosa ilisha) at different stages of processing. $J$ Bangladesh Agril Univ, 9:339-344, 2011.

77.ICMSF (International commission on microbiological specifications for foods) 
Sampling plans for fish and shellfish. In ICMSF (eds). Microorganisms in Foods 2. Sampling for Microbiological Analysis: Principles and Scientific Applications. 2nd edition, Toronto: University of Toronto Press, pp. 181-196, 1986.

78.Uddin, G. M., Larsen, M. H., Guardabassi, L., and Dalsgaard, A., Bacterial flora and antimicrobial resistance in raw frozen cultured seafood imported to Denmark. $J$ Food Prot, 76:490-499, 2013.

79.Opoku-Nkoom, W., Safety and quality characteristics of freeze-defrost cycles in muscle foods. EC Nutr, 1:140-144, 2015.

80.Chytiri, S., Chouliara, I., Savvaidis, I. N., and Kontominas, M. G., Microbiological, chemical and sensory assessment of iced whole and filleted aquacultured rainbow trout. Food Microbiol, 21:157-165, 2004.

81.Rezaei, M., and Hosseini, S. F., Quality assessment of farmed rainbow trout (Oncorhynchus mykiss) during chilled storage. J Food Sci, 73:93-96, 2008.

82.Gobantes, I., Choubert, G., and Gómez, R., Quality of pigmented (astaxanthin and canthaxanthin) rainbow trout (Oncorhynchus mykiss) fillets stored under vacuum packaging during chilled storage. $J$ Agric Food Chem, 46:4358-4362, 1998.
STRATEVA M., et al.

83.Al-Jasser, M. S., and Al-Jasass, F. M., Study the chemical, physical changes and microbial growth as quality measurement of fish. Annu Res Rev Biol, 4:1406-1420, 2014.

84.Liu, Q., Kong, B., Han, J., Chen, Q., and $\mathrm{He}, \mathrm{X}$., Effects of superchilling and cryoprotectants on the quality of common carp (Cyprinus carpio) surimi: Microbial growth, oxidation, and physiochemical properties. LWT-Food Sci Technol, 57:165171, 2014.

85.Hu, S. M., Zhang, L. N., Luo, Y. K., Song, Y. L., Shen, H. X., and Cui, J. Y., Study on the quality changes of common carp during chilled storage and partial-freezing storage [J]. Fishery Modernization, 5, 2010.

86. Taşkaya, L., Kışla, Ş. Ç. D., and Kılınç, B., Quality Changes of Fish Burger from Rainbow Trout During Refrigerated Storage. Su Ürünleri Dergisi, 20:147-154, 2003.

87.Arannilewa, S. T., Salawu, S. O., Sorungbe, A. A., and Ola-Salawu, B. B., Effect of frozen period on the chemical, microbiological and sensory quality of frozen tilapia fish (Sarotherodun galiaenus). Afr $J$ Biotechnol,4:852-855, 2005. 